\title{
ОСОБЛИВОСТІ СІМЕЙНИХ УЯВЛЕНЬ ДІТЕЙ ПОЗБАВЛЕНИХ БАТЬКІВСЬКОГО ПІКЛУВАННЯ
}

\author{
УДК: 159.923 .2
}

\section{Крупник Іван Романович}

\begin{abstract}
Кандидат психологічних наук, старший викладач кафедри «Загальна та сочіальна психологія», Херсонський державний університет, м. Херсон (Україна)
\end{abstract}

\begin{abstract}
Анотація. У статті висвітлено особливості сімейних уявлень у дітей позбавлених батьківського піклування. Зазначено важливість вибору вікової категорії для якісного дослідження особливостей сімейних уявлень. Охарактеризовані методики, які використані у дослідженні. Уявлення про сім'ю є надважливими у картині світу дитини, від яких залежить планування його подальшого життя. Уявлення про сім'ю, установки, очікування мають великий вплив на взаємини у родині в системах «чоловік-дружина» та «батьки-діти». Відсутність родини, є депривуючим чинником, який негативно впливає на формування сімейних уявлень, а саме на позитивне сприймання майбутнього шлюбу взагалі, на їх сформованість, на ставлення до виконання батьківських обов 'язків, тощо.
\end{abstract}

Ключові слова: уявлення про майбутню родину, родинна депривація, діти позбавлені батьківського піклування.

Постанока проблеми. Уявлення людини про себе, про своє місце в суспільстві є одним із наріжних каменів соціальної психології. Фундамент вивчення проблеми соціальних уявлень, до яких, безумовно, відносяться також і уявлення про майбутню сім'ю, заклали французькі соціальні психологи С. Московічі, Ж. Абрік, Д. Жоделе та інші $[9 ; 10 ; 13 ; 17]$. Базуючись на працях М. Вебера та Е. Дюркгейма, які розуміли соціальні уявлення як знання, що приймаються більшістю людей впливаючи на їх діяльність[13], соціальні уявлення, на думку представників цієї школи, формуються в результаті впливу, навіювання соціуму на особистість. Вітчизняні психологи дотримуються схожих поглядів. Зокрема, С. Л. Рубінштейн розглядав уявлення як образи, які виникають у свідомості і мають надважливе значення для свідомого психічного життя, оскільки вони, базуючись на особистому досвіді, надають людині змогу планувати своє майбутнє. Уявлення як внутрішній план дій, як перспектива майбутнього представлені у працях П. Я. Гальперіна [7; 15]. Таким чином, соціальні уявлення виконують функції адаптації до ситуацій, орієнтації поведінки. 


\section{Аналіз останніх досліджень i} публікацій. Уявлення особистості про свій майбутній життєвий шлях та перспективи, зокрема образ майбутньої сім'ї вивчали: К. О. Абульханова-Славська, Т. В. Андрєєва, Е. Г. Ейдемілер, Т. П. Ємельянова та інші [1; $3 ; 9]$.

3 точки зору вказаних дослідників моделі поведінки у родині, подружні та батьківські, формують у дитини уявлення про побудову та взаємовідносини у своїй майбутній сім'ї. Так наприклад, Розроблена К. О. Абульхановою-Славською концепція життєвої стратегії містить компонент уявлення про майбутнє життя у вигляді життєвої перспективи та життєвих планів [1]. Таким чином уявлення про сім'ю, установки, очікування справляють великий вплив на взаємовідносини майбутнього подружжя.

Процес становлення життєвої перспективи в багатьох аспектах залежить від сімейних відношень у батьківській родині. Е. Г. Ейдемілер та В. В. Юстицький вважають, що образ родини залежить від сукупності уявлень про сценарну поведінку кожного члена сім'ї. На їх думку, сімейні уявлення - досить стійкі утворення, вони впливають на сприймання сімейних ситуацій та забезпечують типове реагування, оскільки уявлення про більшість ситуацій у вигляді типових сценаріїв сформоване у людини ще до того, як вона з ними зіштовхнеться. Поняття: що таке сім'я, що означає гарна сім'я, для чого вона потрібна сфор- мовані в дитинстві слугують орієнтирами в розбудові та критеріями оцінки своєї родини. О. П. Чернов уявлення про сім'ю пропонує представити у вигляді мисленнєвих моделей. Це означає, що особистість перед початком взаємодії у сім'ї прогнозує, як будуть розвиватися події, як прореагують інші члени родини на його дії [16]. Будь-яка модель будується на зразках. Саме батьки надають зразки взаємовідносин та утворюють моделі, якими керується наступне покоління. Ставши дорослою, особистість може прийняти таку модель або знехтувати. Це стосується безлічі соціальних ролей, в тому числі і таких, які використовуються у подружньому житті. Традиції, шаблони взаємовідносин, норми спілкування та поведінки передаються із покоління в покоління.

Одним із вірогідних наслідків відсутності батьків є труднощі у повноцінному засвоєнні ролей батьків, чоловіка або дружини, тобто у дитини виникає викривлення та затримка розвитку уявлень про свою майбутню родину.

Знаходячись у деприваційній ситуації у наслідку незадоволення потреб у батьківській увазі, любові, спілкуванні дитина може засвоїти або первинну для неї, деструктивну або ідеалізовану модель сім'ї та сформувати на цій основі образ власної родини. Через це ймовірні проблеми у майбутньому сімейному житті цілком виправдано з наукової точки зору розглядати у контексті родинної депривацiï. 
Класичні дослідження впливу сімейної депривації на особистість дитини Дж. Боулбі, Д. В. Віннікотта, Й. Лангмейера, 3. Матейчика, Г. М. Прихожан, Н. М. Толстих та роботи сучасних науковців О. Г. Алєксєєнкової, Г. М. Бевз, Я. О. Гошовського, Г. М. Лялюк обгрунтовують труднощі та нестійкість сімей утворених вихованцями дитячих будинків дією родинної депривації [2; $4 ; 5 ; 6 ; 8 ; 11 ; 12 ; 14]$.

Зокрема видатні дослідники впливу психічної депривації на дітей, які виховуються поза родиною, Й. Лангмейер, 3. Матейчик висували гіпотезу стосовно передачі негативних характеристик у подружніх стосунках наступному поколінню та вказували на те, що депривована дитина може виявити у майбутньому неспроможність у ролі батька чи матері [12].

Слід також зазначити, що в Україні продовжує залишатися надзвичайно високою кількість вихованців дитячих будинків та шкіл-інтернатів. Так, на 1 січня 2016 року, у різних сирітських закладах перебувало 73 тисяч дітей.

Дослідження образу майбутньої сім'ї у підлітків, які виховуються в закладах інтернатного типу, на нашу думку, дозволять зробити припущення, наскільки благополучні, психологічно зрілі сім’ї вони створять у дорослому житті.

Мета статті. Висвітлити особливості уявлень про майбутню сім'ю підлітків, позба- влених батьківського піклування. Зважаючи на надважливість для гармонійного розвитку особистості дитини фізичної присутності батьків, в тому числі, на іï визначальний вплив на розвиток сімейних уявлень, ми можемо припустити, що відмінності результатів дослідження у дітей-сиріт визначаються саме впливом сімейної депривації. На відміну від дітейсиріт, категорія, яка не входять в сферу впливу родинної депривації - діти 3 повних функціональних сімей.

Для розв'язання поставлених завдань були використані методи:

- теоретичні: аналіз, синтез, порівняння, узагальнення, інтерпретація та систематизація - для з'ясування стану розробленості проблеми;

- емпіричні: психодіагностичні методики: опитувальники «Превентивна задоволеність шлюбом» С.В. Ковальова - для виявлення рівня позитивного ставлення до майбутнього шлюбу та тест «Ваша потреба у дітях»для з'ясування соціально-психологічної бажаності появи своїх дітей, ставлення до можливих труднощів при догляді за ними; Малюнкова методика «Моя майбутня сім'я» для виявлення емоційного ставлення до майбутньої родини та можливих проблемних сімейних уявлень, які можуть впливати деструктивно на подружні та дитячо-батьківські стосунки. Окрім того, проективна методика була використана для перевірки даних, отриманих за допомогою тестів-опитувальників. Вказані 
методики у комплексному застосуванні, дають змогу дослідити особливості уявлень про майбутнє сімейне життя у дітей підліткового віку за найважливішими критеріями, а саме: відношення до дітей та їх виховання, розуміння функцій батьківства, вказують на рівень сформованості сімейних уявлень, усвідомлення своєї відповідальності за інших членів родини, виявляють позитивне або негативне відношення до свого майбутнього подружнього життя.

- методи математичної статистики: описова статистика - для визначення середніх, мінімальних, максимальних показників у групі, показників стандартного відхилення; tкритерій Ст'юдента та $\varphi$-критерій Фішера для перевірки достовірності розбіжностей сімейних уявлень про майбутню родину між вибірками.

Експериментальною базою дослідження були наступні навчально-виховні заклади: Херсонська ЗОШ I-III ступенів №32 та «Навчально-виховний комплекс ім. Т.Г. Шевченко Херсонської обласної ради». До загальної вибірки увійшли діти підліткового віку 13 -14 років у кількості 86 осіб. Кількість дітей з повних родин всього 43 респондента (3 них 23 респондента жіночої статі); дітей позбавлених батьківського піклування всього 43 дитини (з них 25 респондентів жіночої статі).

Вікова категорія досліджуваних повинна бути надчутлива до впливу родинної депривації та знаходитись у сензитивному пері- оді розвитку уявлень про сім’ю. Виходячи 3 проведеного теоретичного аналізу досліджень родинних уявлень, вважаємо, що найбільш прогностичною має бути вибірка дітей пубертатного періоду. У підлітковий період особистість достатньо зріла, щоб мати своє унікальне бачення майбутньої сім’і, і в той же час, це надчутливий вік до відсутності батьківської уваги. Бачення життєвої стратегії, свого місця у дорослому житті, уявлення про нові соціальні ролі, в тому числі подружні та батьківські, знаходяться у цьому віковій стадії на піці свого розвитку. Внаслідок чого якість, насиченість найближчого соціуму або, навпаки, його обмеженість, нестача контактів із значимими дорослими відіграє визначальну роль у їх формуванні.

Аналіз та інтерпретація результатів тесту «Превентивна задоволеність шлюбом» показав у обох вибірках досить високий piвень превентивного задоволення шлюбом. У дітей, позбавлених батьківського піклування цей показник дорівнює 65,3\%. В інтерпретації до тесту зазначено, що високий рівень починається з 66\%, отже ми бачимо високі результати у даних досліджуваних групах. Тобто свій майбутній шлюб уявляється в досліджуваній вибірці позитивно. Але значно вищий показник $є$ у дітей з повних функціональних родин 73,3\%. Можемо припустити, що цей результат обумовлений наявністю реального взірця успішного батьківського шлюбу та особистим психологічним комфортом дітей з по- 
вних родин, оскільки на них не діє родинна депривація. В свою чергу, брак прикладів позитивного сімейного життя та незадоволення багатьох вищих потреб дитини знижує превентивну задоволеність майбутнім шлюбом. Результати свідчать про відмінність між вибірками в уявленнях про майбутнє сімейне життя $\mathrm{i}$ надає можливість припустити, що ця відмінність обумовлена впливом родинної депривації. Результати розподілу в процентному відношенні показано на рисунку 1.

На графіку показано, що високий рівень превентивної задоволеності шлюбом мають 71,4\% дітей 3 функціональних родин та $44,2 \%$ дітей-вихованців школи-інтернату. Найбільша частка за середнім рівнем належить дітям, позбавленим батьківського піклування $-53,5 \%$. Важливо відмітити, що низький рівень у процентному розподілі є тільки у ви-
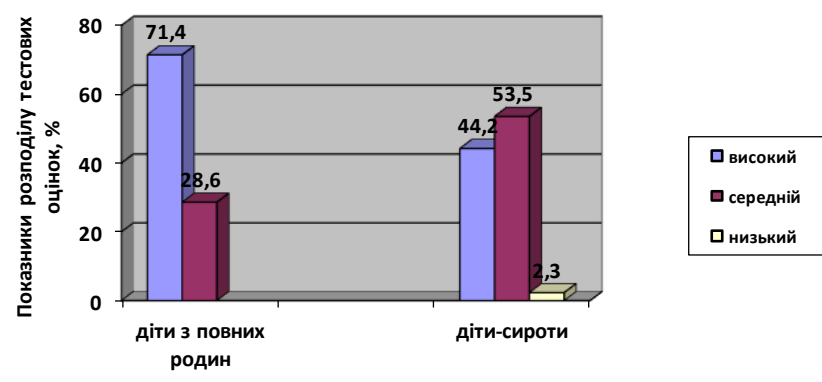

Рис. 1. Відсотковий розподіл тестових оцінок за методикою «Превентивна задоволеність шлюбом» С.В. Ковальова.

бірці дітей-сиріт. Таким чином незважаючи на достатньо високі результати у вибірці дітейсиріт, у процентному відношенні виявлені значні відмінності між показниками вибірок.
За допомогою t-критерію Ст'юдента було підтверджено виявлені відмінності між середнім балом показника можливої майбутньої задоволеності шлюбом у вибірках дітей 3 повних родин та дітей які виховуються у сиротинцях (див. табл. 1).

Виявлена статистично значуща відмінність $(\mathrm{t}=2,83 \mathrm{P} \leq 0,05)$ між середнім балом рівня превентивної задоволеності шлюбом дітей позбавлених батьківського піклування та дітей $з$ родин. Це свідчить, що такий важливий

Таблиия 1

Значущі відмінності тестових оцінок за методикою «Превентивна задоволеність шлюбом» С.В. Ковальова (t-критерій Ст'юдента)

\begin{tabular}{|l|l|l|l|}
\hline Вибірка & $\begin{array}{l}\text { Сер. } \\
\text { бал }\end{array}$ & $\begin{array}{c}\text { t-критерій } \\
\text { Ст'юден- } \\
\text { та }\end{array}$ & $\begin{array}{l}\text { Рівень } \\
\text { значущос- } \\
\text { ті }\end{array}$ \\
\hline Діти - сироти & 65,3 & & \multirow{2}{*}{2,83} \\
\cline { 1 - 2 } $\begin{array}{c}\text { Діти з пов- } \\
\text { них родин }\end{array}$ & 73,3 & & \\
\hline
\end{tabular}

аспект образу майбутньої родини, як бажаність шлюбу, його позитивне сприйняття у дітей які виховуються в сиротинцях суттєво знижений у порівнянні 3 дітьми з повних функціональних родин. На нашу думку такі розбіжності можуть бути тому що, діти які виховуються в сиротинцях, не мають позитивних прикладів шлюбу, вони самі не відчули в достатній мірі батьківської любові, і тому відно- 
сяться до можливості подружнього життя 3 острахом, не надто сподіваючись на його успішність.

Таким чином, незважаючи на схожі високі результати по загальній вибірці, виявлено статистично значущі розбіжності у результатах, що говорить про відмінності в уявленнях про майбутнє сімейне життя у дітей-сиріт та дітей з повних родин. Ці відмінності доводять, що вказані особливості обумовлені дією родинної депривації на дітей - сиріт.

Аналіз та інтерпретація результатів показників методики «Ваша потреба в дітях».

За методикою «Ваша потреба в дітях» були отримані такі середні значення у цілому за тестом: 96,69 балів у дітей 3 повних родин та 95,75 балів у дітей позбавлених батьківського піклування. При можливому максимальному результаті за окремим запитанням в чотири бали та 124 бали за відповіді за всією методикою, більшість респондентів отримали досить високі показники. Невелика частка значень ідентичні або дуже близькі у загальній виборці (наприклад «народження дитини це радість у домі» або «можливість виростити добру, гарну людину»), однак більшість результатів вказують на значну різницю сімейних уявлень дітей-сиріт від уявлень дітей 3 повних родин. Середні результати показників дітей - сиріт у порівнянні із вибіркою дітей 3 повних родин представлені у таблиці 2. При аналізі розбіжностей показників по запитаннях слід відмітити, що діти сироти вбачають у своєму батьківстві менше позитивних моментів, ніж діти 3 іншої вибірки. Вони будуть менше пишатися своїми нащадками та не вважають, що діти акумулюють кращі риси своїх батьків, вважають, що виховання, це втрата кращої частини життя, що діти прив'язують до дому.

Окрім того, з точки зору дітей-сиріт, батьківство несе безліч труднощів як фізичних так і моральних (проблема житла; метушня 3 пелюшками, пляшками; розлад, напруга в сіM’̈̈).

У дітей $з$ повних родин у процентному відношенні майже у всіх респондентів виявлено високий рівень потреби у дітях, а саме 95,3\%. Тільки у одного респондента вказаної вище вибірки середній показник та одного низький показник потреби у дітях. У дітей сиріт у процентному співвідношенні середній показник рівня потреби у дітях більш виражені 16,3\%. Унікальність родинних уявлень підкреслюється відмінностями у значеннях показників рівня вираженості потреби в дітях, виявлених за допомогою $\varphi$-критерію Фішера стосовно високого рівня (див. табл. 3).

Згідно критерію Фішера існує значуща розбіжність у показниках високого рівня за методикою «Ваша потреба у дітях» $(\varphi=4,6$; $\mathrm{P} \leq 0,01)$.

Ці дані слугують достатньою підставою для висновку: особливості уявлень про майбутню родину дітей-сиріт найбільш торкаються батьківського потенціалу, невпевненос- 


\section{Середні значення результатів за методикою «Ваша потреба в дітях»}

\begin{tabular}{|c|c|c|c|}
\hline № & Народження дитини це... & Діти - сироти & $\begin{array}{l}\text { Діти із звичайних } \\
\text { родин }\end{array}$ \\
\hline 1 & нові, благотворні враження & 3,51 & 3,25 \\
\hline 2 & радість у домі & 3,81 & 3,81 \\
\hline 3 & можливість проявити свою ніжність та турботу & 3,72 & 3,71 \\
\hline 4 & великі фізичні навантаження & 2,58 & 2,46 \\
\hline 5 & дитяча ласка, прив’язаність до матері, батька & 3,67 & 3,72 \\
\hline 6 & помічник в сім'ї, опора на старості & 3,70 & 3,35 \\
\hline 7 & можливість виростити освічену, цікаву людину & 3,79 & 3,54 \\
\hline 8 & спадкоємець всього гарного в мені & 3,42 & 3,16 \\
\hline 9 & труднощі у вихованні та навчанні & 2,44 & 2,60 \\
\hline 10 & розлад, напруга в сім’ї & 2,98 & 3,21 \\
\hline 11 & матеріальні труднощі & 2,93 & 2,86 \\
\hline 12 & надія і майбутне батьків & 3,56 & 3,65 \\
\hline 13 & необхідність на якийсь час залишити роботу, колектив & 2,07 & 2,17 \\
\hline 14 & безсонні ночі & 2,19 & 2,19 \\
\hline 15 & можливість проявити свої виховні здібності & 3,30 & 3,48 \\
\hline 16 & зміцнення сім'ї та почуттів між подружжям & 3,47 & 3,59 \\
\hline 17 & можливість виростити добру, гарну людину & 3,72 & 3,71 \\
\hline 18 & радість материнства (батьківства) & 3,81 & 3,86 \\
\hline 19 & метушня з пелюшками, пляшками & 2,35 & 2,08 \\
\hline 20 & проблема житла & 3,16 & 3,40 \\
\hline 21 & найвдячніший об’єкт для вкладання наших сил & 3,53 & 3,37 \\
\hline 22 & зіткнення з труднощами влаштувати в ясла, садок & 2,51 & 2,71 \\
\hline 23 & прив’язати себе до дому & 2,37 & 2,70 \\
\hline 24 & втрата кращої частини нашого життя & 3,16 & 3,61 \\
\hline 25 & надання сенсу життю & 3,28 & 3,25 \\
\hline 26 & хвилювання за її долю, майбутнє & 1,23 & 1,25 \\
\hline 27 & складність дати гарну освіту, професію & 2,12 & 2,40 \\
\hline 28 & втіха у горі та радості & 3,60 & 3,40 \\
\hline 29 & залежність від бабусь та дідусів & 2,51 & 2,70 \\
\hline 30 & гордість для батьків & 3,35 & 3,78 \\
\hline 31 & веселі ігри і змістовне дозвілля & 3,53 & 3,73 \\
\hline
\end{tabular}

\section{Значущі відмінності тестових оцінок за методикою «Ваша потреба в дітях» ( $\varphi$-критерій Фішера)}

Таблиия 3

\begin{tabular}{|c|c|c|c|c|}
\hline $\begin{array}{c}\text { Потреба в дітях } \\
\text { (\%) }\end{array}$ & $\begin{array}{l}\text { Діти з повних роди } \\
(\mathrm{n}=43)\end{array}$ & Діти-сироти (n=43) & Критерій Фішера & $\begin{array}{c}\text { Рівень значи- } \\
\text { мості }\end{array}$ \\
\hline Високий рівень & 95,3 & 83,7 & 4,6 & $\mathrm{P} \leq 0,01$ \\
\hline
\end{tabular}

ті у своїх виховних здібностях. Респонденти не бажають терпіти фізичні або моральні навантаження у процесі піклування про дітей.
На нашу думку таке ставлення у майбутньому може призвести до небажання займатися вихованням вже своїх дітей. 
Аналіз та інтерпретація результатів за проективною малюнковою методикою «Моя майбутня сім'я».

Розбіжності виявлені за допомогою tкритерію Ст'юдента між показниками малюнкової методики «Моя майбутня сім'я» у вибірках дітей-сиріт та дітей які живуть у родинах (див. табл. 4).

Порівнюючи отримані результати між вибірками дітей $з$ сиротинців та повних сімей за t-критерієм Ст'юдента, була виявлена статистично значуща відмінність $(\mathrm{t} .=3,35$; $\mathrm{P} \leq 0,01) \quad$ за середнім балом показника свідчить як про краще усвідомлення майбутнього образу родини так і про позитивне емоційне відношення до нього

Виявлена статистично значуща відмінність за показником критерію «Опрацьованість малюнка, велика кількість різноманітних деталей», як було зазначено вище, при аналізі середніх балів даного показника вказує на більш позитивне ставлення до майбутньої сім'ї, оскільки діти працювали із задоволенням, постійно щось домальовували, не жаліли часу для малювання. Окрім того, якісніше створений малюнок, вказує на різно-

\section{Значущі відмінності показників сімейних уявлень (малюнок «Моя майбутня сім'я»)}

\begin{tabular}{|c|c|c|c|c|}
\hline \multirow{2}{*}{$\begin{array}{l}\text { Критерії оцінювання малюн- } \\
\text { ка }\end{array}$} & $\begin{array}{l}\text { Діти сироти } \\
\quad(\mathrm{n}=43)\end{array}$ & $\begin{array}{c}\text { Діти } 3 \text { повних } \\
\text { родин } \\
(\mathrm{n}=43) \\
\end{array}$ & \multirow{2}{*}{$\begin{array}{l}\text { t-критерій } \\
\text { Ст’юдента }\end{array}$} & \multirow[t]{2}{*}{ Рівень значущості } \\
\hline & Середній бал & Середній бал & & \\
\hline $\begin{array}{l}\text { Проробленість } \\
\text { (опрацьованість) малюнка, } \\
\text { велика кількість різноманіт- } \\
\text { них деталей }\end{array}$ & 0,14 & 0,42 & 3,35 & $\mathrm{P} \leq 0,01$ \\
\hline Загальний бал за методикою & 3,99 & 4,96 & 1,98 & $\mathrm{P} \leq 0,05$ \\
\hline
\end{tabular}

«проробленість малюнка» та за загальним середнім балом показників за оцінюваними критеріями (t. $=1,98 ; \mathrm{P} \leq 0,05)$.

Пропрацьованість малюнка представляється нам показником позитивного ставлення до майбутньої сім'ї (підлітки, які створили малюнки більш якісні, малювали з радістю та зацікавленістю) та свідченням більш виразного, реального її баченням. Тобто більш детально промальований досліджуваний матеріал бічні, виразніші, більш сформовані сімейні уявлення. Виявлена статистично значуща відмінність між показниками середніх балів за усією методикою доводить значну відмінність між сімейними уявленнями вибірок дітей 3 повних сімей та дітей-вихованців школиінтернату у цілому. Таким чином, майбутню родину діти 3 повних сімей уявляють більш згуртованою, в якій присутні батько та мати i діти, вони взаємодіють як в системі «чоловік- 
дружина» та і в системі «батьки -діти».

Слід зазначити, що виявлені відмінності підкреслюються загальною тенденцією у результатах показників середніх балів за усіма критеріями (див. табл. 5).

Розглянемо критерії, різниця показників яких не є статистично значущими, але при їх комплексному аналізі із статистично значущими показниками, особливості сімейних уявлень дітей які виховуються в сиротинцях бу- нкціональних родин. Слід зазначити, що під загальною діяльністю малися на увазі спільна гра або праця (підлітки часто малювали поїздку на відпочинок (на машині, літаку). Даний показник вказує на важливість в уявленнях підлітків спільної взаємодії в родинах. Таким чином у дітей сиріт, такий важливий аспект життєдіяльності родини менш виражений у порівнянні 3 дітьми 3 повних родин оскільки діти сироти не мають можливості спостерігати

\section{Середні значення показників сімейних уявлень у підлітків за малюнковою методикою} «Моя майбутня сім'я»

\begin{tabular}{|l|l|l|l|}
\hline $\begin{array}{l}\text { № } \\
\text { ח }\end{array}$ & \multicolumn{1}{|c|}{ Критерії оцінки } & $\begin{array}{l}\text { Діти з повних родин } \\
\text { (середній бал по крите- } \\
\text { рію) } \\
(\mathrm{n}=43)\end{array}$ & $\begin{array}{l}\text { Діти-сироти (середній } \\
\text { бал по критерію) } \\
(\mathrm{n}=43)\end{array}$ \\
\hline 1 & Наявність спільної діяльності батьків & 0,64 & 0,5 \\
\hline 2 & Наявність дітей & 0,87 & 0,72 \\
\hline 3 & Присутність обох батьків & 0,86 & 0,79 \\
\hline 4 & Спільна діяльність батьків і дітей & 0,51 & 0,35 \\
\hline 5 & Відсутність конфліктів, показників ворожості & 0,88 & 0,8 \\
\hline 6 & Опрацьованість малюнка, велика кількість & & 0,42 \\
\hline 7 & Візноманітних деталей & 0,78 & 0,14 \\
\hline
\end{tabular}

дуть охарактеризовані більш повно та різнобічно. Простежимо результати вибірок за показником «спільна діяльність батьків»: середні бали показників - 0,5 у дітей сиріт та 0,64 у дітей $з$ повних родин. Взаємодія членів родини у цілому за загальною вибіркою, відображалась частіше у малюнках дітей з повних фу- взаємодію дорослих та дітей у родині. Зважаючи на те, що спільна діяльність $є$ основою взаєморозуміння у родині низькі показники за цим критерієм можуть у майбутньому сімейному житті підлітків виявитись причиною конфліктів.

Показник «наявність дітей» (середні 
бали показників: 0,72 у дітей сиріт та 0,87 у дітей 3 повних родин). Вихованці інтернату в меншій мірі зображали на малюнках дітей. Виявлена тенденція може вказувати на меншу значущість дітей для майбутньої родини, що підтверджується результатами отриманими за допомогою опитувальника «Ваша потреба в дітях». Можливо таке відношення виникає внаслідок васного досвіду покинутості своїми батьками та через страхи труднощів які виникнуть на їх думку при вихованні дітей.

Показники «присутність обох батьків» та «спільна діяльність батьків і дітей» (середні бали показників: 0,79 та 0,35 у дітей сиріт, 0,86 та 0,51 у дітей 3 повних родин відповідно). Уявлення сім’ї, в якій батьки разом, відображені у малюнках в більшій мірі у дітей 3 повних родин. Виявлені тенденції висвітлюють різницю в уявленнях про майбутню родину респондентів досліджуваних вибірок, а саме проблемність, нецільність образу у дітей позбавлених батьківської опіки. Наявність у сім'ї як батька так і матері не є для них визначальною для розуміння родини. На малюнках респондентів 3 вибірки дітей-сиріт навіть якщо батьки присутні, вони майже не взаємодіють як в системі «чоловік-дружина» та і 3 дітьми.

Результати за показником «наявність ізольованих фігур», свідчить про те, що діти 3 повних сімей, уявляють свою майбутню родину більш цілісною, згуртованою (середні бали показників: 0,70 у дітей сиріт та 0,78 у дітей 3 повних родин). Відстань між окремими персонажами, наявність певних бар'єрів між людьми частіше зустрічається на малюнках дітейсиріт (навіть коли на малюнку зображено ситуацію спільного відпочинку). Що свідчить про негативну емоційну налаштованість до членів родини, бажання відокремитись.

Узагальнюючи, слід підкреслити, що наявність вищих результатів показників за більшістю критеріїв у дітей 3 повних родин вказує на те що образ майбутньої родини у дітейсиріт менш чіткий, недостатньо сформований, невиражені тенденції до спільної взаємодії у системах «чоловік-дружина» та «батьки-діти», що може у майбутньому призводити до створення психологічно неблагополучних родин. Члени родини уявляються окремо один від одного, вони не схильні до взаємодії. Виявлені розбіжності підтверджують висновки, які були зроблені після аналізу результатів показників рівня превентивної задоволеності шлюбом та потреби в дітях, а саме респонденти 3 вибірки дітей позбавлених батьківського піклування менш позитивно сприймають свою майбутню родину взагалі, знижена бажаність свого батьківства, менше уваги приділено спільній взаємодії між членами родини.

Узагальнення результатів дослідження дає підстави для таких висновків:

1. Образ майбутньої власної сім'ї - досить складне утворення, яке складається з ідеології родини або сімейних міфів, гомеостазу сім’ї, життєвого сценарію та сімейних комуні- 
кацій, цінностей та правил, як загальнолюдських так і унікальних, характерних для даної родини, які включають уявлення про розподіл обов'язків та функцій, уявлень про сімейну ієрархію.

При відсутності взаємодії «батькидіти» виникає деприваційна ситуація, в результаті уявлення про майбутню родину у дітей набуають специфічних ознак: вони менш реалістичні, не наповнені конкретикою, тобто взагалі властивою рисою для депривованої особистості є відсутність чітких уявлень про сімейне життя. Психіка дитини в умовах родинної депривації інфантилізується, що в майбутньому призводить до труднощів у сімейному житті. Депривована дитина в результаті гірше підготовлена до виконання соціальних ролей, в тому числі і до виконання функцій батьківства. У дитини, яка знаходиться у ситуації родинної депривації деформація торкається не тільки уявлень про майбутнє сімейне життя, а й уражає більш глобальне утворення - загальний образ світу, який теж має фрагментарний та несформований, нереалістичний характер 3 негативним емоційним фоHOM.

2. Порівняльний аналіз результатів емпіричного дослідження особливостей уявлень про майбутнє сімейне життя дітей 3 повних родин і дітей, позбавлених батьківського піклування, дав змогу виявити значущі розбіжності, а саме:

Встановлено, що за результати показ- ників у дітей-сиріт отриманими в результаті психодіагностичного обстеження, достовірно відрізняються від показників респондентів 3 іншої вибірки, що вказує на зумовленість особливостей сімейних уявлень підлітків позбавлених батьківського піклування впливом родинної депривації.

Значущі відмінності у сімейних уявленнях дітей з родин та дітей, позбавлених батьківського піклування, стосуються як превентивної задоволеності шлюбом, потреби в дітях так і загальної сформованістю образу майбутньої родини.

У дітей позбавлених батьківського піклування спостерігається байдуже ставлення до своїх нащадків, яке проявляється у негативному відношенні до догляду за дитиною, її вихованням, до виконання домашніх обов'язків. Респонденти вважають, що майбутня родина це джерело труднощів як фізичних так і фінансових, пов'язаних з піклуванням про дітей. На їх думку виховання дітей займає занадто багато часу. Окрім того вони вважають, що вкладати зусилля у розвиток дітей не має сенсу, оскільки діти не виправдають надії батьків, не зможуть бути опорою у старості, не стануть спадкоємцями гарних якостей. Такі уявлення $є$ проявом їх невпевненості у своїх виховних здібностях.

Уявлення про майбутню родину у дітей позбавлених батьківського піклування гірше сформовані, менш позитивні, не насичені ситуаціями взаємодії як між подружжям так i 
дітей з батьками.

\section{Перспективи подальших досліджень} вбачаються у грунтовному вивченні факторів, які впливають на особливості уявлень дітей, позбавлених батьківського піклування про майбутнє сімейне життя та розробці на цій основі психологічного супроводу підлітків даної категорії.

\section{Перелік використаних джерел:}

1. Абульханова-Славская К. А. Стратегия жизни / Абульханова-Славская К.А. - М. : Мысль, 1991. - 299 с.

2. Алексеенкова Е. Г. Личность в условиях психической депривации: Учебное пособие / Е.Г. Алексеенкова. СПб.: Питер, 2009. - 96 с.

3. Андреева T. В. Семейная психология: Учеб. пособие / Т.В. Андреева. - СПб. : Речь, 2004. - 244 с.

4. Бевз Г. Прийомні сім’ї / Г. Бевз. - К.: Главник, 2006. $-112 \mathrm{c}$.

5. Боулби Д. Создание и разрушение эмоциональных связей / Д. Боулби. - М.: Академический Проект, 2004. $-232 \mathrm{c}$.

6. Винникотт Д. Семья и развитие личности. Мать дитя / Д. Винникот. - Екатеринбург : Литург, 2004. - 400 c.

7. Гальперин П. Я. Лекции по психологии [учеб. пособ. для студ. вузов]. - М.: Университет, 2002. - 399 с.

8. Гошовський Я. О. Психолого-педагогічні основи ресоціалізації депривованих підлітків : автореф. дис. на здобуття наук. ступеня доктора психол. наук : спец. 19.00.07 «Педагогічна та вікова психологія» / Я.О. Гошовський. - К, 2009. - 43 с.

9. Емельянова Т. П. Социальное представление - понятие и концепция: итоги последнего десятилетия / Т.П. Емельянова // Психологический журнал. - 2001. - Т. 22, № 6. - C. 39-47.

10. Жоделе Д. Социальные представления как эле- менты, опосредующие отношение к отклонению / Д. Жоделе // Психоанализ и науки о человеке. - М. : Прогресс-Культура, 1995. - С. 155-190.

11. Лангмейер Й. Психическая депривация в детском воздасте / 3. Матейчик, Й. Лангмейер. - Прага: Авиценум, 2009. - $162 \mathrm{c}$.

12. Лялюк Г. М. Психологічні особливості соціалізації підлітків в умовах родинної депривації : автореф. дис. на здобуття наук. ступеня канд. психол. наук : спец. 19.00.07 «Педагогічна та вікова психологія» / Г.М. Лялюк. - Івано-Франківськ, 2007. - 23 с.

13. Московичи С. От коллективных представлений к социальным (кистории одного понятия) / С. Московичи // Вопросы социологии. - 1992. - Т.1, №2. - С. 27-29 14. Прихожан А. М. Психология сиротства / А.М. Прихожан, Н.Н. Толстых. - СПб.: Питер, 2005. - 400 с.

15. Рубинштейн С. Л. Проблемы общей психологи / С.Л. Рубинштейн. - М., «Педагогика», 1973. - 424 с.

16. Эйдемиллер Э. Г. Психология и психотерапия семьи / Э.Г. Эйдемиллер, В.В. Юстицкис. - [4-е изд.] СПб. : Питер, 2008. - 672 с.

17. Codol J. P. On the system of representatations in a group situation. - Europ. J. Soc. Psychol., 1974, N 4(3), P. 343-365.

\section{References (Transliteration):}

1. Abul'hanova-Slavskaja K. A. Strategy of Life / Abu'hanova-Slavskaja K.A. - M. : Mysl', 1991. - 299 s. (in Russian)

2. Alekseenkova E. G. Psychical Personality in Conditions of Mental Deprivation / E.G. Alekseenkova. - SPb.: Piter, 2009. - 96 s. (in Russian)

3. Andreeva T. V. Family Psychology / T.V. Andreeva. $\mathrm{SPb}$. : Rech, 2004. - 244 s. (in Russian)

4. Bevz Gh. Foster Families / Gh. Bevz. - K.: Ghlavnyk, 2006. -112 s. (in Ukrainian)

5.Boulbi D. Creation and Destruction of Emotional Relations / D. Boulbi. - M.: Akademicheskij Proekt, 2004. 
-232 s. (in Russian)

6. Emel'janova T. P. Social Representation - Concept and Conception: the Results of the Last Decade / T.P. Emel'janova // Psihologicheskij zhurnal. - 2001. - T. 22, \# 6. - S. 39-47. (in Russian)

7. Gal'perin P. Ja. Lectures in Psychology. - M.: Universitet, 2002. - 399 s. (in Russian)

8. Ghoshovsjkyj Ja. O. Psycho-pedagogical Foundations of Resocialization of Deprived Adolescents: avtoref. dys. na zdobuttja nauk. stupenja doktora psykhol. nauk : spec. 19.00.07 «Pedaghoghichna ta vikova psykhologhija» / Ja.O. Ghoshovsjkyj. - K, 2009. - 43 s. (in Ukrainian)

9. Jejdemiller Je. G. Psychology and Psychotherapy of the Family / Je.G. Jejdemiller, V.V. Justickis. - SPb. : Piter, 2008. - 672 s. (in Russian)

10. Langmejer J. Mental Deprivation in Childhood / Z. Matejchik, J. Langmejer. - Praga: Avicenum, 2009. - 162 s. (in Russian)

11. Ljaljuk Gh. M. Psychological Peculiarities of Socialization of Adolescents in Conditions of Family Deprivation : avtoref. dys. na zdobuttja nauk. stupenja kand. psykhol. nauk : spec. 19.00.07 «Pedaghoghichna ta vikova psykhologhija» / Gh.M. Ljaljuk. - Ivano-Frankivsjk, 2007. - 23 s. (in Ukrainian)

12. Moskovichi S. From Collective Perception to Social / S. Moskovichi // Voprosy sociologii. - 1992. - T.1, \#2. - S. 27-29 (in Russian)

13. Prihozhan A. M. Psychology of Orphanage / A.M. Prihozhan, N.N. Tolstyh. - SPb.: Piter, 2005. - 400 s.

14. Rubinshtejn S. L. Problems of General Psychology / S.L. Rubinshtejn. - M., «Pedagogika», 1973. - 424 s.

15. Vinnikott D. Family and the Development of Personality. Mother Child / D. Vinnikot. - Ekaterinburg : Liturg, 2004. - $400 \mathrm{~s}$.

16. Zhodele D. Social Representations as Elements Mediating Attitudes to Deviation / D. Zhodele // Psihoanaliz i nauki o cheloveke. - M. : Progress-Kul'tura, 1995. - S. 155-190. (in Russian)
17. Codol J. P. On the system of representatations in a group situation. - Europ. J. Soc. Psychol., 1974, N 4(3), P. 343-365. (in English)

\section{Krupnik Ivan}

Candidate of Psychological Sciences, Senior Lecturer of the Department of "General and Social Psychology", Kherson State University, Kherson (Ukraine)

\section{PECULIARITIES OF FAMILY CONCEPTS OF CHILDREN DEPRIVED OF PARENTAL CARE}

\section{ABSTRACT}

In the article peculiarities of family concepts of children deprived of parental care are considered. The importance of choosing of an age category for qualitative research of the peculiarities of family concepts is emphasized. The technics used in the study are characterized. Ideas about the family are very important in the picture of the child's world, because the planning of his future life depends on them. The concept of the family, attitudes, expectations have a great influence on the relationship in the family in the "husband-wife" and "parent-child" systems.

The absence of a family is a deprivational factor, which negatively affects the form of family concept, namely, the positive perception of the future marriage, its formation, attitude to parental responsibilities. Comparative analysis of the results of empirical research of features ideas about future family life of children from full families and children deprived of parental care, has allowed to reveal significant differences, namely: it is established that the results of the indicators of orphan children received as a result of psychodi- 
agnostic examination, significantly differ from those of respondents from the other sample, indicating the dependence features of family of representations of teenagers deprived of parental care, the influence of family deprivation. Significant differences in family representations of children from their families and children deprived of parental care relating to as a preventive of satisfaction with the marriage, demand for children and the image of the future family. Children deprived of parental care observed indifference to their offspring, which manifests itself in a negative attitude to child care, her discipline, to perform household duties. The idea of the future family, children deprived of parental care worse formed, less positive, intense situations of interaction between spouses and between children and parents.

The prospects of further researches are seen in a thorough examination of factors that affect perceptions of children deprived of parental care, family life and the development on this basis, the psychological support of adolescents in this category.

Key words: the concept of the future family, family deprivation, children deprived of parental care.

\section{Крупник Иван Романович}

Кандидат психологических наук, старший преподаватель кафедры «Общая и сочииальная психология», Херсонский государственный университет, 2. Херсон (Украина)

\section{ОСОБЕННОСТИ СЕМЕЙНЫХ}

\section{ПРЕДСТАВЛЕНИЙ ДЕТЕЙ ЛИШЕННЫХ РОДИТЕЛЬСКОЙ ОПЕКИ}

Аннотация. В статье рассмотрены особенности семейных представлений у детей лишенных родительской опеки. Отмечена важность выбора возрастной категории для качественного исследования особенностей семейных представлений. Охарактеризованы методики, которые использованы в исследовании.

Представления о семье являются сверхважными в картине мира ребенка, так как от них зависит планирование его дальнейшей жизни. Представление о семье, установки, ожидания имеют большое влияние для взаимоотношений в семье в системах «муж-жена» и «родители-дети». Отсутствие семьи, является депривирующим фактором, который негативно влияет на формирование семейных представлений, а именно на позитивное восприятие будущего брака, на их сформированность, на отношение к родительским обязанностям.

Целью статьи является исследование особенностей представлений о будущей семье у подростков, лишенных родительской опеки. Исследование образа будущей семьи у подростков, воспитывающихся в учреждениях интернатного типа, позволят сделать предположение насколько благополучные, психологически зрелые семьи они создадут во взрослой жизни.

Сравнительный анализ результатов эм- 
пирического исследования особенностей представлений о будущей семейной жизни детей из полных семей и детей, лишенных родительской опеки, позволил выявить значимые различия, а именно: установлено, что за результаты показателей у детей-сирот, полученные в ходе психодиагностического обследования, достоверно отличаются от показателей респондентов из выборки детей, которые проживают в полных функциональных семьях, что указывает на обусловленность особенностей семейных представлений подростков лишенных родительской опеки влиянием семейной депривации. Значимые различия о семейных представлениях детей из семей и детей, лишенных родительской опеки, касаются как превентивной удовлетворенности браком, потребности в детях так и общей сформированности образа будущей семьи. У респондентов, воспитывающихся в интернатах, наблюдается безразличное отношение к своим будущим детям, которое проявляется в отрицательном отношении к уходу за ребенком, его воспитанием, к выполнению домашних обязанностей. Таким образом представление о будущей семье у детей лишенных родительской опеки хуже сформированы, менее позитивные, насыщенные ситуациями взаимодействия как между супругами, так и детей с родителями.

Перспективы дальнейших исследований видятся в детальном изучении факторов, которые влияют на особенности представле- ний детей, лишенных родительской опеки семейной жизни и разработке на этой основе психологического сопровождения подростков данной категории.

Ключевые слова: представление о будущей семье, семейная депривация, лишенные родительской заботы дети.
Дата отримання статті: 15.12 .2017

Дата рекомендації до друку: 20.12.2017 